\title{
Increased CLA content in organic milk fermented by bifidobacteria or yoghurt cultures
}

\author{
Ana Carolina Rodrigues Florence ${ }^{1}$, Roberta Claro DA SILVA ${ }^{1}$, \\ Ana Paula do Espírito SAnto ${ }^{1}$, Luiz Antonio Gioieldi ${ }^{1}$, Adnan Y. TAmime ${ }^{2}$, \\ Maricê Nogueira DE OLIVEIRA ${ }^{1 *}$ \\ ${ }^{1}$ Department of Biochemical and Pharmaceutical Technology, São Paulo University, \\ Ave. Prof. Lineu Prestes 580, 05508-900 São Paulo, Brazil \\ 24 Queens Terrace, Ayr KA7 1DX, Scotland, UK
}

Received 10 October 2008 - Accepted 1st June 2009

Published online 23 September 2009

\begin{abstract}
This study investigates the kinetics of acidification, fatty acid (FA) profile and conjugated linoleic acid (CLA, C18:2 $c 9, t 11$ ) content in fermented milks prepared from organic and conventional milk. Fermented milks were manufactured with five mixed cultures: four different strains of Bifidobacterium animalis subsp. lactis (BL04, B94, BB12 and HN019) and Lactobacillus delbrueckii subsp. bulgaricus LB340, in co-culture with Streptococcus thermophilus TA040. The composition of milk was evaluated, and the kinetics of acidification was followed by continuous $\mathrm{pH}$ measurement using the Cinac system. The profile of FA, including CLA, was analyzed by gas chromatography. The chemical composition of conventional and organic milk was similar, with the exception of protein and $\mathrm{Fe}$, the concentrations of which were higher in the organic milk. The rate of acidification was significantly influenced by the type of milk and the bacterial strain used. Co-cultures St-HN019 and St-BB12 showed higher maximal acidification rates in both milks. Final counts of $S$. thermophilus (9.0-10.1 $\log _{10}$ colony forming units $\left.(\mathrm{CFU}) \cdot \mathrm{mL}^{-1}\right)$, Lactobacillus bulgaricus (8.2-8.5 $\left.\log _{10} \mathrm{CFU} \cdot \mathrm{mL}^{-1}\right)$ and $B$. animalis subsp. lactis strains $\left(8.3-9.3 \log _{10}\right.$ $\mathrm{CFU} \cdot \mathrm{mL}^{-1}$ ) did not differ significantly in either milk. Unexpectedly, all fermented organic milks contained significantly higher amounts of CLA than the same milk before fermentation, whereas CLA amounts did not change during fermentation of conventional milk. Regardless of the type of milk, CLA was found to be significantly positively correlated with trans-vaccenic acid and negatively correlated with linoleic acid. Moreover, the CLA contents were significantly higher in fermented milks showing shorter fermentation times.
\end{abstract}

acidification profile / fermented milk / Bifidobacterium animalis subsp. lactis / organic milk / conjugated linoleic acid / trans-vaccenic acid

摘要 - 双歧杆菌或酸奶发酵剂发酵的高 CLA 含量的有机发酵乳。本文研究了有机和普通发 酵乳的酸化动力学、脂肪酸特性和共轭亚油酸 (CLA, C18:2 $c 9, t 11$ ) 的含量。用 5 种混 合发酵剂发酵牛乳，4 株 Bifidobacterium animalis subsp. lactis (BL04、B94、BB12、HN019) 和 1 株 Lactobacillus delbrueckii subsp. bulgaricus LB340 分别与 Streptococcus thermophilus TA040 共培养。研究了乳的组成成分, 通过连续测定的 $\mathrm{pH}$ 值来评价酸化动力学。采用气 相色谱法分析了脂肪酸及共轭亚油酸组成。除了有机乳的蛋白质和铁浓度高于普通乳外, 两 种乳的化学组成基本上相同; 乳的类型和发酵菌株则显著地影响了乳的酸化速率。在两种原

*Corresponding author (通讯作者): monolive@usp.br 
料乳中, St-HN019 和 St-BB12 共发酵菌株表现出最大的酸化速率; S. thermophilus $\quad(9.0 \sim 10.1$ $\log _{10}$ cfu $\left.\cdot \mathrm{mL}^{-1}\right) 、 L$. bulgaricus $\left(8.2 \sim 8.5 \log _{10} \mathrm{cfu} \cdot \mathrm{mL}^{-1}\right)$ 和 $B$. animalis subsp. lactis strains $\left(8.3 \sim 9.3 \log _{10} \mathrm{cfu} \cdot \mathrm{mL}^{-1}\right)$ 在两种乳中的最后菌数没有显著差异。出乎意料的是有机乳发 酵后 CLA 含量显著地提高, 但是普通乳发酵前后 CLA 含量没有变化。如果不考虑乳的 类型, CLA 含量与反式一十八碳烯酸呈正相关, 与亚油酸含量呈负相关。此外, 发酵时 间短的发酵乳中 CLA 含量较高。

\section{酸化特性 / 益生性发酻乳 / 有机乳 / 共轭亚油酸 / 反式-十八碳烯酸}

Résumé - Teneur en acide linoléique conjugué accrue dans des laits biologiques fermentés par des bifidobactéries et des levains à yaourt. Cette étude a pour but d'examiner les cinétiques d'acidification, les profils en acides gras et les teneurs en acide linoléique conjugué (CLA, C18:2 $c 9, t 11)$ de laits fermentés préparés à partir de lait biologique et conventionnel. Des laits fermentés ont été produits avec cinq types de cultures mixtes : quatre souches de Bifidobacterium animalis subsp. lactis (BL04, B94, BB12 et HN019) et Lactobacillus delbrueckii subsp. bulgaricus LB340, en co-culture avec $S$. thermophilus TA040. La composition du lait était évaluée et les cinétiques d'acidification étaient suivies par mesure continue du $\mathrm{pH}$ à l'aide du système Cinac. Les profils en acides gras incluant le CLA étaient analysés par chromatographie en phase gazeuse. Le lait conventionnel et le lait biologique avaient une composition chimique proche, à l'exception des teneurs en protéine et en fer, qui étaient plus élevées dans le lait biologique. La vitesse d'acidification était significativement influencée par le type de lait et les souches bactériennes utilisées. Dans les deux laits, la vitesse d'acidification maximale la plus élevée a été observée pour les co-cultures St-HN019 et St-BB12. Les dénombrements finaux de S. thermophilus $\left(9,0\right.$ à $\left.10,1 \log _{10} \mathrm{CFU} \cdot \mathrm{mL}^{-1}\right)$, de L. bulgaricus $\left(8,2\right.$ à $\left.8,5 \log _{10} \mathrm{CFU} \cdot \mathrm{mL}^{-1}\right)$ et de $B$. animalis subsp. lactis $\left(8,3\right.$ à $9,3 \log _{10}$ $\left.\mathrm{CFU} \cdot \mathrm{mL}^{-1}\right)$ ne différaient pas de façon significative dans les deux laits. De façon inattendue, tous les laits biologiques fermentés contenaient des teneurs significativement plus élevées en CLA que le même lait avant fermentation, alors que les teneurs en CLA ne variaient pas au cours de la fermentation dans le lait conventionnel. Quel que soit le type de lait, le CLA était positivement corrélé à l'acide trans-vaccénique et négativement à l'acide linoléique. De plus, les teneurs en CLA étaient significativement plus élevées dans les laits fermentés ayant des temps de fermentation courts.

cinétique d'acidification / lait fermenté / Bifidobacterium animalis subsp. lactis / lait biologique / acide linoléique conjugué / acide trans-vaccenique

\section{INTRODUCTION}

Organic methods of food production have gained increased public interest over the last couple of decades, and this concept of agriculture has grown considerably, mainly, in the western world. Organic products have been identified to contain a higher nutritional quality compared to conventional food and, as a consequence, have attracted consumer acceptability [5]. Organic and conventional dairy productions differ considerably in feeding regimens, in the use of antibiotic and chemotherapeutic treatments and in the handling of animals [12]. However, all the standards of organic farming specify strict rules for milk production and feeding of dairy cattle. The feed must be obtained from organic farming where the use of any artificial input is forbidden [23]. The chemical composition of organic and conventional dairy products has been analyzed and compared by many researchers $[32,36]$ in order to support and prove the authenticity on the benefits of a natural livestock system. These studies showed that there are little or any differences in the compositional data.

Milk and dairy products are an important source of conjugated linoleic acid (CLA), which consists of a mixture of positional and geometric isomers of linoleic acid (C18:2) with conjugated double bonds. The main isomer is the cis-9, trans-11, but less 
amounts of trans-9, trans-11 and trans-10, cis-12 are also formed [5, 6, 38]. Milk and dairy products have been shown to contain the highest amounts of CLA [5, 38], and it is produced as an intermediate component in the ruminal biohydrogenation pathway, carried out by the rumen bacteria. The dietary lipids that are hydrolyzed into free fatty acids (FA) are subjected to biohydrogenation in the digestive tract of ruminants and, as a consequence, the biohydrogenation pathway is the major source of CLA in milk fat $[15,30]$.

CLA formation by bacterial strains has been documented since the early 1960s [27]. For example, propionibacteria (i.e. as adjunct culture and possibly lactic acid bacteria) [28] and some yoghurt starter cultures $[7,37]$ showed potential as food-grade organisms to be used for CLA enhancement in dairy products. In yoghurt, there is a certain potential to increase the CLA content by adding adjunct cultures under the condition that free linoleic acid or oil and suitable lipase are added; this approach of increasing the CLA level in the fermented milk has its limitation(s) [37]. The substrate level in the growth media may be a key factor for CLA production, since a high level of unsaturated long-chain fatty acids (LCFA) is believed to be inhibitory not only to cell growth but also to the overall biohydrogenation steps, especially for gram-positive bacteria, which lack an outer membrane [21].

The interest in the possible ability of dairy starter cultures to increase the CLA content in dairy products is vast. As a significant proportion of the CLA isomers are formed during biohydrogenation of linoleic acid in the rumen by the bacteria Butyrivibrio fibrisolvens, it was to be expected that bacteria used as dairy starter cultures would also have the ability to form CLA [7]. Many researchers investigated the synthesis of CLA using selected bacterial strains under controlled conditions in laboratory media or model systems [11, 28, 37]. Some of these selected strains include lactobacilli, bifidobacteria and propionibacteria, which were found to convert efficiently the added linoleic acid to CLA.

CLA in fermented milk and dairy products should provide "functional" aspects as inhibition of initiation of carcinogenesis process, effects on anti-atherogenic, anti-adipogenic, anti-diabetogenic and antiinflammatory activities, beneficial regulatory effects on immune function, and alters the low-density lipoprotein/high-density lipoprotein cholesterol ratio $[8,15]$.

During fermentation, many bioactive components are formed [34], as organic acids (lactic, pyruvic, formic, acetic and propionic), peptides derived from milk proteins due to proteolysis [16], and acetaldehyde, acetone, acetoin and biacetyl through carbohydrates degradation [20]. The CLA amounts could be enhanced through biohydrogenation of linoleic acid by bifidobacteria and other bacteria [24]. To date, few studies have explored the effect of bifidobacteria and yoghurt starter cultures on growth and acidification kinetics as well as the identification of bioactive components in organic fermented milk.

The aims of this study were to investigate the performance of different strains of Bifidobacterium animalis subsp. lactis on acidification and FA profile including CLA in organic and conventional fermented milk.

\section{MATERIALS AND METHODS}

\subsection{Milk}

Commercial organic and conventional pasteurized whole milks were purchased from a local supermarket and used for the manufacture of yoghurt and probiotic fermented milks.

\subsection{Chemical composition of milk (organic and conventional)}

Fat, protein, total solids and density contents were determined using an ultrasonic 
milk analyzer Ekomilk (Eon Trading, Bulgaria), an equipment that analyzes the milk composition by ultrasound; the analysis was done according to the recommendations of Venturoso et al. [35]. Lactose and lactic acid contents were determined according to the guidelines of Instituto Adolfo Lutz [17], and a digital potentiometer (Quimis, Diadema, São Paulo) was used to measure the $\mathrm{pH}$ values.

Calcium $(\mathrm{Ca})$, magnesium $(\mathrm{Mg})$, copper $(\mathrm{Cu})$, iron $(\mathrm{Fe})$ and zinc $(\mathrm{Zn})$ contents in the fresh milk were determined using an atomic absorption spectrophotometer (Polarized Zeeman AAS, Hitachi Z-5000; Hitachi, Tokyo, Japan). A hollow cathode lamp was employed at 422.7, 202.6, $324.8,283.4$ and $213.9 \mathrm{~nm}$, and slits of $0.7,1.3,1.3,0.2$ and $1.3 \mathrm{~nm}$ for measuring the $\mathrm{Ca}, \mathrm{Mg}, \mathrm{Cu}, \mathrm{Fe}$ and $\mathrm{Zn}$ contents, respectively, after wet digestion $\left(\mathrm{HNO}_{3}: \mathrm{H}_{2} \mathrm{O}_{2}-\right.$ $\left.5: 1 ; \mathrm{mL} \cdot 100 \mathrm{~mL}^{-1}\right)$ and addition of $0.1 \%$ $\left(\mathrm{g} \cdot 100 \mathrm{~g}^{-1}\right)$ lanthanum as $\mathrm{La}_{2} \mathrm{O}_{3}$ (for $\mathrm{Ca}$ and $\mathrm{Mg}$ analyses) as recommended by the AOAC [3]. The working standard solutions $\left(100 \mathrm{mg} \cdot \mathrm{mL}^{-1}\right)$ were prepared with $\mathrm{CaCl}_{2}$, $\mathrm{MgCl}_{2}, \mathrm{CuCl}_{2}, \mathrm{FeCl}_{3}$ and $\mathrm{ZnCl}_{2}$, and were obtained from Titrisol Merck, Darmstadt, Germany. All the chemical analyses were performed in duplicate.

\subsection{Sources of microbial cultures and enumeration}

Concentrated and freeze-dried single strains of probiotic and yoghurt microflora were employed: S. thermophilus (St-) strain TA040 (Danisco, Sassenage, France), Lactobacillus delbrueckii subsp. bulgaricus strain LB340 (Danisco, Sassenage, France), B. animalis subsp. lactis strain BB12 (Chr. Hansen A/S, Hoersholm, Denmark), strain BL04 (Danisco, Madison, USA), strain B94 (DSM Food Specialities, New South Wales, Australia) and strain HN019 (Danisco, Madison, USA). Each lyophilized strain was weighed and dissolved in 50-mL sterilized skimmed milk $\left(121{ }^{\circ} \mathrm{C}\right.$ for $15 \mathrm{~min}$ ) that had been tempered to $42{ }^{\circ} \mathrm{C}$ for $15 \mathrm{~min}$ before use. One milliliter of each rehydrated culture was inoculated in $500 \mathrm{~mL}$ of organic and conventional milk (treated at $85{ }^{\circ} \mathrm{C}$ for $15 \mathrm{~min}$ ). This procedure allowed us to obtain initial counts of $\sim 8.0 \log _{10}$ colony forming units (CFU) $\mathrm{mL}^{-1}$.

Enumeration was made, in duplicate, one day after fermentation of the stored products at $4{ }^{\circ} \mathrm{C}$, as no changes in bacteria counts between the end of fermentation and $24 \mathrm{~h}$ after the process were observed. Each sample $(1.0 \mathrm{~mL})$ was added to $9.0 \mathrm{~mL}$ of $0.1 \% \quad\left(\mathrm{~g} \cdot 100 \mathrm{~mL}^{-1}\right)$ sterile peptonized water and then appropriate dilutions were made. Subsequently, $S$. thermophilus and L. delbrueckii subsp. bulgaricus were plated into M17 agar and MRS agar (Oxoid Ltd., Basingstoke, UK); the latter agar was previously acidified to $\mathrm{pH} 5.4$ with acetic acid, and afterward the plates were incubated at $37^{\circ} \mathrm{C}$ for $48 \mathrm{~h}$ [10]. B. animalis subsp. lactis strains were enumerated in RCA agar adjusted to $\mathrm{pH} 7.1$ added with $0.3 \mathrm{~g} \cdot 100 \mathrm{~g}^{-1}$ of aniline plus $1 \mu \mathrm{L} \cdot \mathrm{mL}^{-1}$ of dicloxacillin and incubated under anaerobic conditions at $37^{\circ} \mathrm{C}$ for $72 \mathrm{~h} \mathrm{[29].}$

Anaerobic conditions were ensured by the use of AnaeroGen (Oxoid Ltd., Basingstoke, UK). The enumeration of microbial counts was performed on plates containing 30-300 colonies. Microscopic examination of the cells in the colonies of every strain of bifidobacteria was performed using a light microscope.

\subsection{Fermented milk manufacture}

Organic and conventional pasteurized whole milks were heat treated to $85{ }^{\circ} \mathrm{C}$ for 15 min in a water bath (Lauda ${ }^{\circledR}$-Königshofen, Germany) under constant stirring, cooled to $10{ }^{\circ} \mathrm{C}$ and stored overnight at $4{ }^{\circ} \mathrm{C}$. On the following day, each type of milk was tempered to $42{ }^{\circ} \mathrm{C}$, divided into five batches 
and inoculated with different combinations of starter cultures. Each batch of milk was incubated at $42{ }^{\circ} \mathrm{C}$ in a thermostatically controlled water bath until the $\mathrm{pH}$ reached 4.7. The rate of acidification of each of the microbial blends was monitored using the Cinac system (Ysebaert, Frépillon, France). After reaching a $\mathrm{pH}$ of 4.7 , each fermented milk was agitated manually using a stainless steel plunger (i.e. consisting of a rod and perforated disk) that was moved upward and downward for $60 \mathrm{~s}$, dispensed into $50-\mathrm{mL}$ polypropylene cups (heat sealed using Selopar equipment - BrasHolanda, Pinhais, Brazil), quickly cooled in an ice bath and stored at $4{ }^{\circ} \mathrm{C}$ until required for analysis. The samples were prepared in duplicate, and the experiment was replicated twice on different days.

Five kinetic parameters were considered: (a) $V_{\max }$ [maximum acidification rate, measured in $\mathrm{pH}$ units per $\left.\min \left(\mathrm{upH} \cdot \mathrm{min}^{-1}\right)\right]$, (b) $T_{V_{\max }}$ (time to reach the maximum acidification rate), (c) $\mathrm{pH}$ corresponding to $V_{\max }$ and (d) $T_{\mathrm{pH} 5.0}$ and $T_{\mathrm{pH} 4.7}$ (time in hours to reach $\mathrm{pH} 5.0$ and 4.7, respectively).

\subsection{FA and CLA analysis}

Lipids were extracted from fresh milk, yoghurts and probiotic fermented milk products (organic and conventional) according to the ISO method 14156 ISO [18], and the fatty acid methyl esters (FAMEs) were prepared by esterification according to the ISO method 15884 ISO [19].

Analyses of FAMEs were carried out in a gas chromatograph, Model 3400CX (Varian, São Paulo, Brazil) equipped with a splitinjection port, a flame-ionization detector and a software package for system control and data acquisition (model Star Chromatography Workstation version 5.5, Varian Inc., Palo Alto, CA). Injections were performed in a $30 \mathrm{~m}$ long fused silica capillary column with $0.25-\mathrm{mm}$ internal diameter, coated with $0.25 \mu \mathrm{m}$ of Chrompack CP-Wax 52CB (Chrom Tech, Apple Valley, MN, USA), using helium as carrier gas at a flow rate of $1.5 \mathrm{~mL} \cdot \mathrm{min}^{-1}$ and a split ratio of 1:50. The injector temperature was set at $250{ }^{\circ} \mathrm{C}$ and that of the detector at $280^{\circ} \mathrm{C}$. The oven temperature was inigramed to increase to $150{ }^{\circ} \mathrm{C}$ at a rate of $37.5^{\circ} \mathrm{C} \cdot \mathrm{min}^{-1}$ and then to $215^{\circ} \mathrm{C}$ at a rate of $3{ }^{\circ} \mathrm{C} \cdot \mathrm{min}^{-1}$. Samples $(1 \mu \mathrm{L})$ were injected manually after a dwell time of ca. $2 \mathrm{~s}$.

Qualitative FA composition of the samples was determined by comparing the retention times of the peaks produced after injecting the methylated samples with those of the respective standards of FA (SIGMA 05632 and SIGMA 189-19). CLA (cis-9, trans-11) was detected at $23.10 \mathrm{~min}$ of retention time. The quantitative composition of each FA was calculated from the area of each peak and expressed as a percentage according to the Official Method Ce 1-62 [4]. The FA composition was classified as reported by Ackman [1] who described short-chain fatty acids (SCFA) as $\mathrm{C} 2$ to $\mathrm{C} 4$, medium-chain fatty acids (MCFA) as C6 to C12 and LCFA as C14 to $\mathrm{C} 24$. All samples were analyzed in quadruplicate, and the results, expressed as $\mathrm{g} \cdot 100 \mathrm{~g}^{-1}$ of total FA, were reported as mean value.

\subsection{Statistical analysis}

Analysis of variance for multiple comparisons using Statistica 6.0, Statsoft (Tulsa, USA), was performed in order to confirm the statistical significance of differences among samples $(P<0.05)$. Mean values were compared using the Tukey test at $P \leq 0.05$.

Coefficient $(r)$ was calculated in order to estimate the correlation between linoleic acid (C18:2), trans-vaccenic acid (TVA) $(\mathrm{C} 18: 1 t)$, CLA (C18:2 $c 9, t 11)$ and 
Table I. Gross chemical composition* and certain minerals of organic and conventional fresh milk.

\begin{tabular}{lcc}
\hline Component & \multicolumn{2}{c}{ Milk } \\
\cline { 2 - 3 } & Organic & Conventional \\
\hline Fat $\left(\mathrm{g} \cdot 100 \mathrm{~g}^{-1}\right)$ & $3.60 \pm 0.03$ & $3.65 \pm 0.04$ \\
Protein $\left(\mathrm{g} \cdot 100 \mathrm{~g}^{-1}\right)$ & $3.72 \pm 0.03^{\mathrm{b}}$ & $3.24 \pm 0.04^{\mathrm{a}}$ \\
Lactose $\left(\mathrm{g} \cdot 100 \mathrm{~g}^{-1}\right)$ & $4.56 \pm 0.03$ & $4.55 \pm 0.02$ \\
Total solids $\left(\mathrm{g} \cdot 100 \mathrm{~g}^{-1}\right)$ & $12.51 \pm 0.11$ & $12.18 \pm 0.05$ \\
Lactic acid $\left(\mathrm{g} \cdot 100 \mathrm{~g}^{-1}\right)$ & $0.15 \pm 0.01$ & $0.15 \pm 0.01$ \\
$\mathrm{pH}$ & $6.62 \pm 0.01$ & $6.66 \pm 0.02$ \\
Density $\left(\mathrm{g} \cdot \mathrm{cm}^{-3}\right)$ & $1.032 \pm 0.001$ & $1.030 \pm 0.001$ \\
$\mathrm{Ca}\left(\mathrm{mg} \cdot \mathrm{g}^{-1}\right)$ & $1.874 \pm 0.144$ & $1.874 \pm 0.160$ \\
$\mathrm{Mg}\left(\mathrm{mg} \cdot \mathrm{g}^{-1}\right)$ & $0.094 \pm 0.014$ & $0.091 \pm 0.017$ \\
$\mathrm{Cu}\left(\mu \mathrm{g} \cdot \mathrm{g}^{-1}\right)$ & $0.082 \pm 0.012$ & $0.073 \pm 0.013$ \\
$\mathrm{Fe}\left(\mu \mathrm{g} \cdot \mathrm{g}^{-1}\right)$ & $0.514 \pm 0.113^{\mathrm{b}}$ & $0.415 \pm 0.083^{\mathrm{a}}$ \\
$\mathrm{Zn}\left(\mu \mathrm{g} \cdot \mathrm{g}^{-1}\right)$ & $3.470 \pm 0.200$ & $3.616 \pm 0.314$ \\
\hline
\end{tabular}

* Mean values $(n=12) \pm$ standard deviation with different letters in the same line are significantly different $(P \leq 0.05)$.

fermentation time $\left(T_{\mathrm{pH} 4.7}\right)$ in organic and conventional milk, considering $P \leq 0.01$.

\section{RESULTS AND DISCUSSION}

\subsection{Chemical composition of milk}

The chemical composition $\left(\mathrm{g} \cdot 100 \mathrm{~g}^{-1}\right)$ of conventional and organic milk was closely related, did not present any significant differences and is shown in Table I. The protein content, however, was significantly higher in organic milk. $\mathrm{Ca}, \mathrm{Zn}, \mathrm{Mg}$ and $\mathrm{Cu}$ contents did not significantly differ in both types of milks, but the Fe content was higher in organic milk. Such data are similar to what has been reported by the researchers in different countries $[9,33]$.

\subsection{Acidification kinetics}

The acidification rates in milk (organic and conventional) of yoghurt starter organisms and different strains of $B$. animalis subsp. lactis (B94, BB12, BL04 and HN019) in co-culture with $S$. thermophilus are shown in Table II. Comparison of the acidification kinetics of the four strains of $B$. animalis subsp. lactis grown in conventional and organic whole milk revealed different results. Co-cultures St-HN019 and St-BB12 showed a higher acidification rate $\left(V_{\max }\right)$ in both milks. The time to reach $V_{\max }$ $\left(T_{V_{\max }}\right)$ for St-B94, St-BL04 and St-LB340 was significantly higher $(P \leq 0.05)$ in conventional milk than in organic milk. The $\mathrm{pH}$ at which $V_{\max }$ was reached, $\mathrm{pH}_{V_{\max }}$, did not significantly differ between co-cultures and between milks.

The time to reach $\mathrm{pH} 5.0, T_{\mathrm{pH} 5.0}$, was significantly higher for St-B94 and StBL04 in conventional milk when compared with organic milk. Fermentation of the conventional milk with co-culture St-B94 required $6.00 \mathrm{~h}$ to reach $\mathrm{pH} 4.7$, but the same co-culture required $4.17 \mathrm{~h}$ to reach the same value of $\mathrm{pH}$ in organic milk, i.e. a decrease of $24.5 \%$ in the fermentation time (Fig. 1). Similarly, yoghurt starter cultures and co-culture St-BL04 showed a significantly shorter time of fermentation in organic milk than in conventional milk. In spite of the absence of the published data, 
Table II. Comparison of the acidification kinetic parameters in organic and conventional milk by the yoghurt cultures (St-LB340 - control), and S. thermophilus in co-culture with the four strains of B. animalis subsp. lactis (St-BB12, St-B94, St-BL04 and St-HN019).

\begin{tabular}{lcccccc}
\hline Milk & Product & Co-culture & $\begin{array}{c}V_{\max } \\
\left(10^{-3} u \mathrm{uH}^{-1} \min ^{-1}\right)\end{array}$ & $T_{V_{\max }}(\mathrm{h})$ & $\mathrm{pH}_{V_{\max }}$ & $T_{\mathrm{pH} 5.0}(\mathrm{~h})$ \\
\hline Organic & Y & St-LB340 & $17.40 \pm 0.42^{\mathrm{a}}$ & $2.62 \pm 0.07^{\mathrm{ab}}$ & $5.39 \pm 0.01^{\mathrm{a}}$ & $3.12 \pm 0.02^{\mathrm{a}}$ \\
& FM & St-BB12 & $18.36 \pm 0.08^{\mathrm{a}}$ & $2.72 \pm 0.02^{\mathrm{ab}}$ & $5.53 \pm 0.05^{\mathrm{abc}}$ & $3.50 \pm 0.05^{\mathrm{abc}}$ \\
& FM & St-B94 & $18.19 \pm 0.42^{\mathrm{a}}$ & $2.62 \pm 0.16^{\mathrm{abc}}$ & $5.49 \pm 0.08^{\mathrm{abc}}$ & $3.30 \pm 0.42^{\mathrm{bc}}$ \\
& FM & St-BL04 & $18.19 \pm 0.28^{\mathrm{a}}$ & $2.70 \pm 0.00^{\mathrm{ab}}$ & $5.45 \pm 0.09^{\mathrm{ab}}$ & $3.29 \pm 0.12^{\mathrm{ab}}$ \\
& FM & St-HN019 & $24.42 \pm 0.01^{\mathrm{b}}$ & $2.62 \pm 0.07^{\mathrm{ab}}$ & $5.63 \pm 0.06^{\mathrm{abc}}$ & $3.37 \pm 0.00^{\mathrm{abc}}$ \\
& Y & St-LB340 & $18.87 \pm 2.42^{\mathrm{a}}$ & $3.20 \pm 0.18^{\mathrm{cd}}$ & $5.51 \pm 0.08^{\mathrm{abc}}$ & $3.79 \pm 0.12^{\mathrm{cd}}$ \\
& FM & St-BB12 & $23.82 \pm 1.25^{\mathrm{b}}$ & $2.65 \pm 0.03^{\mathrm{ab}}$ & $5.79 \pm 0.01^{\mathrm{c}}$ & $3.63 \pm 0.00^{\mathrm{bc}}$ \\
& FM & St-B94 & $17.95 \pm 2.23^{\mathrm{a}}$ & $3.77 \pm 0.09^{\mathrm{e}}$ & $5.79 \pm 0.14^{\mathrm{c}}$ & $4.78 \pm 0.07^{\mathrm{c}}$ \\
& FM & St-BL04 & $17.75 \pm 0.83^{\mathrm{a}}$ & $3.32 \pm 0.02^{\mathrm{d}}$ & $5.54 \pm 0.13^{\mathrm{abc}}$ & $4.12 \pm 0.16^{\mathrm{d}}$ \\
& FM & St-HN019 & $24.38 \pm 0.59^{\mathrm{b}}$ & $2.55 \pm 0.03^{\mathrm{a}}$ & $5.74 \pm 0.01^{\mathrm{bc}}$ & $3.42 \pm 0.05^{\mathrm{abc}}$ \\
\hline
\end{tabular}

Abbreviations: Y, yoghurt; FM, fermented milk; $V_{\max }$, maximum acidification rate; $T_{V_{\max }}$, time to reach $V_{\max } ; \mathrm{pH}_{V_{\max }}, \mathrm{pH}$ in $V_{\max }$ and $T_{\mathrm{pH} 5.0}$, time to reach $\mathrm{pH}$ 5.0. Mean values $(n=4)$ with different letters in the same column are significantly different $(P \leq 0.05)$.

a lower fermentation time of organic milk was unexpected. This result may be related to the presence of some organic acids, as formic acid, in organic milk due to handling of the animals (feeding regimen, no use of antibiotic and chemotherapeutic treatments).

To our knowledge, there are no data available on the kinetic profile of $B$. animalis subsp. lactis in organic milk. On the other hand, the acidification times results obtained from the co-cultures St-LB340 and St-BL04 in conventional milk were much lower than those reported by Almeida et al. [2] and by Oliveira and Damin [25].

\subsection{Probiotic and yoghurt starter culture counts}

Table III details the microbial counts of the yoghurt starter cultures and the bifidobacteria in the inoculated milk (D0) and (D1), i.e. $24 \mathrm{~h}$ after the fermentation period in the stored products at $4{ }^{\circ} \mathrm{C}$. The average increase in the counts of all the microorganisms in organic and conventional milk products was $1.09 \quad \log _{10}$ and
$1.22 \log _{10}$ cycles, respectively. Some differences were observed for $B$. animalis subsp. lactis counts concerning all products. Strains of $B$. animalis subsp. lactis reached on average $8.60 \log _{10} \mathrm{CFU} \cdot \mathrm{mL}^{-1}$ in organic and $8.75 \log _{10} \mathrm{CFU} \cdot \mathrm{mL}^{-1}$ in conventional fermented milk with no significant differences. $S$. thermophilus counts did not present significant differences between the different milks, i.e. varying between 9.00 and $10.14 \log _{10} \mathrm{CFU} \cdot \mathrm{mL}^{-1}$ and being at least one order of magnitude higher than the other bacteria (data not shown).

\subsection{FA profile and CLA contents}

Table IV shows the FA contents $\left(\mathrm{g} \cdot 100 \mathrm{~g}^{-1}\right)$ in organic and conventional fresh milk (M), yoghurts (Y) and fermented milk (FM) products prepared with St-LB340 (control) and St-BB12, St-B94, St-BL04 and St-HN019.

No significant differences were found for SCFA contents in organic fresh milk, yoghurt and fermented milk; whereas significant differences $(P \leq 0.05)$ were found 


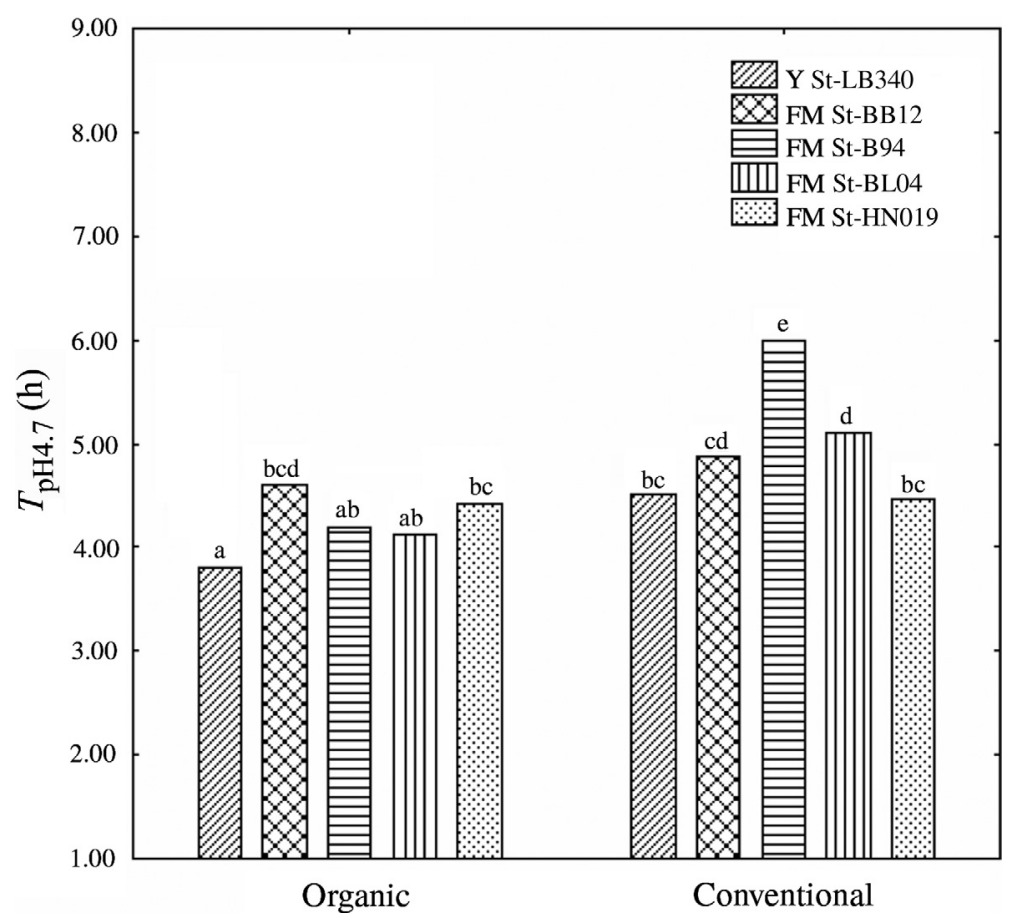

Figure 1. Fermentation time $\left(T_{\mathrm{pH} 4.7}\right)$ of yoghurt cultures (St-LB340 - control), and S. thermophilus in co-culture with the four strains of B. animalis subsp. lactis (St-BB12, St-B94, St-BL04 and St-HN019) in organic and conventional milk. Mean values of duplicate experiments with different letters are significantly different; $P \leq 0.05$.

Table III. Counts of single strains of $L$. delbrueckii subsp. bulgaricus (LB340) and B. animalis subsp. lactis strains (BB12, B94, BL04 and HN019) fermented in co-culture with S. thermophilus in organic and conventional milk $24 \mathrm{~h}$ after the end of fermentation.

\begin{tabular}{lcccc}
\hline Milk & Product & Culture & $\log _{10}$ CFU·mL $\mathrm{mL}^{-1} \mathrm{D} 0$ & $\log _{10} \mathrm{CFU} \cdot \mathrm{mL}^{-1} \mathrm{D} 1$ \\
\hline Organic & Y & LB340 & $7.22 \pm 0.25^{\mathrm{a}}$ & $8.22 \pm 0.32^{\mathrm{cd}}$ \\
& FM & BB12 & $7.45 \pm 0.03^{\mathrm{ab}}$ & $8.69 \pm 0.12^{\mathrm{def}}$ \\
& FM & B94 & $7.54 \pm 0.09^{\mathrm{ab}}$ & $8.35 \pm 0.21^{\mathrm{cde}}$ \\
& FM & BL04 & $7.51 \pm 0.03^{\mathrm{ab}}$ & $8.78 \pm 0.25^{\mathrm{def}}$ \\
Conventional & FM & HN019 & $7.48 \pm 0.02^{\mathrm{ab}}$ & $8.59 \pm 0.16^{\mathrm{de}}$ \\
& Y & LB340 & $7.36 \pm 0.05^{\mathrm{ab}}$ & $8.50 \pm 0.04^{\mathrm{de}}$ \\
& FM & BB12 & $7.80 \pm 0.01^{\mathrm{abc}}$ & $9.26 \pm 0.12^{\mathrm{f}}$ \\
& FM & B94 & $6.89 \pm 0.16^{\mathrm{a}}$ & $8.85 \pm 0.08^{\mathrm{de}}$ \\
& FM & BL04 & $7.89 \pm 0.02^{\mathrm{bc}}$ & $8.50 \pm 0.01^{\mathrm{ef}}$ \\
& FM & HN019 & $7.36 \pm 0.05^{\mathrm{ab}}$ & $8.39 \pm 0.12^{\text {cde }}$ \\
\hline
\end{tabular}

Abbreviations: Y, yoghurt; FM, fermented milk; D0, after inoculating the processed milk; D1, $24 \mathrm{~h}$ after the fermentation period in the stored product at $4{ }^{\circ} \mathrm{C}$. Mean values $(n=4)$ with different letters in the same column are significantly different $(P \leq 0.05)$. 
Table IV. FA contents $\left(\mathrm{g} \cdot 100 \mathrm{~g}^{-1}\right)$ in organic and conventional fresh milk (M), yoghurts (Y) and fermented milk (FM).

\begin{tabular}{|c|c|c|c|c|c|c|c|c|}
\hline Milk source & Product & Co-culture & SCFA & MCFA & LCFA & SFA & MUFA & PUFA \\
\hline \multirow[t]{6}{*}{ Organic } & M & - & $3.20 \pm 0.12^{\mathrm{ab}}$ & $9.04 \pm 0.53^{\mathrm{a}}$ & $87.02 \pm 0.36^{\mathrm{abc}}$ & $66.73 \pm 0.06^{\mathrm{ab}}$ & $29.90 \pm 0.30^{\mathrm{de}}$ & $\overline{3.41 \pm 0.28^{\mathrm{a}}}$ \\
\hline & $\mathrm{Y}$ & St-LB340 & $3.68 \pm 0.50^{\mathrm{ab}}$ & $11.58 \pm 0.59^{\mathrm{b}}$ & $86.95 \pm 1.71^{\mathrm{a}}$ & $64.72 \pm 0.16^{\mathrm{a}}$ & $26.34 \pm 0.76^{\mathrm{a}}$ & $3.27 \pm 0.59^{\mathrm{a}}$ \\
\hline & FM & St-BB12 & $2.71 \pm 0.46^{\mathrm{ab}}$ & $9.75 \pm 0.35^{\mathrm{ab}}$ & $87.18 \pm 0.73^{\mathrm{abc}}$ & $69.63 \pm 3.07^{\mathrm{b}}$ & $28.42 \pm 0.52^{\mathrm{abcd}}$ & $3.71 \pm 0.20^{\mathrm{a}}$ \\
\hline & FM & St-B94 & $3.09 \pm 0.78^{\mathrm{ab}}$ & $10.67 \pm 1.72^{\mathrm{ab}}$ & $87.15 \pm 2.37^{\mathrm{abc}}$ & $68.11 \pm 1.31^{\mathrm{b}}$ & $27.25 \pm 2.17^{\mathrm{ab}}$ & $3.86 \pm 0.70^{\mathrm{a}}$ \\
\hline & FM & St-BL104 & $3.26 \pm 0.86^{\mathrm{ab}}$ & $10.70 \pm 1.12^{\mathrm{ab}}$ & $87.26 \pm 1.99^{\mathrm{abc}}$ & $70.35 \pm 1.32^{\mathrm{c}}$ & $27.90 \pm 1.02^{\mathrm{abc}}$ & $3.75 \pm 0.34^{\mathrm{a}}$ \\
\hline & FM & St-HN019 & $3.24 \pm 0.22^{\mathrm{b}}$ & $8.98 \pm 0.34^{\mathrm{a}}$ & $87.43 \pm 0.27^{\mathrm{bc}}$ & $66.73 \pm 0.05^{\mathrm{ab}}$ & $31.85 \pm 0.12^{\mathrm{e}}$ & $3.45 \pm 0.06^{\mathrm{a}}$ \\
\hline \multirow[t]{6}{*}{ Conventional } & M & - & $2.74 \pm 0.04^{\mathrm{ab}}$ & $8.73 \pm 0.10^{\mathrm{a}}$ & $87.37 \pm 0.13^{\mathrm{c}}$ & $67.06 \pm 0.31^{\mathrm{ab}}$ & $29.48 \pm 0.22^{\mathrm{cd}}$ & $3.73 \pm 0.16^{\mathrm{a}}$ \\
\hline & $\mathrm{Y}$ & St-LB340 & $3.34 \pm 0.09^{\mathrm{ab}}$ & $9.26 \pm 0.74^{\mathrm{a}}$ & $87.10 \pm 0.75^{\mathrm{abc}}$ & $67.90 \pm 0.89^{\mathrm{b}}$ & $28.55 \pm 0.77^{\mathrm{bcd}}$ & $3.55 \pm 0.13^{\mathrm{a}}$ \\
\hline & FM & St-BB12 & $3.51 \pm 0.48^{\mathrm{b}}$ & $10.48 \pm 1.07^{\mathrm{ab}}$ & $87.01 \pm 1.47^{\mathrm{ab}}$ & $68.96 \pm 0.97^{\mathrm{b}}$ & $27.62 \pm 0.83^{\mathrm{abc}}$ & $3.43 \pm 0.14^{\mathrm{a}}$ \\
\hline & FM & St-B94 & $2.77 \pm 0.31^{\mathrm{ab}}$ & $9.44 \pm 0.08^{\mathrm{a}}$ & $87.53 \pm 0.33^{\mathrm{abc}}$ & $66.90 \pm 0.60^{\mathrm{ab}}$ & $29.25 \pm 0.40^{\mathrm{bcd}}$ & $3.85 \pm 0.39^{\mathrm{a}}$ \\
\hline & FM & St-BL04 & $2.98 \pm 1.02^{\mathrm{ab}}$ & $10.51 \pm 0.64^{\mathrm{ab}}$ & $87.40 \pm 1.44^{\mathrm{abc}}$ & $67.91 \pm 1.36^{\mathrm{b}}$ & $27.99 \pm 0.99^{\mathrm{abcd}}$ & $3.62 \pm 0.21^{\mathrm{a}}$ \\
\hline & FM & St-HN019 & $2.13 \pm 0.05^{\mathrm{a}}$ & $9.70 \pm 1.08^{\mathrm{ab}}$ & $87.95 \pm 1.14^{\mathrm{bc}}$ & $67.75 \pm 1.10^{\mathrm{b}}$ & $29.11 \pm 0.97^{\mathrm{bcd}}$ & $3.25 \pm 0.18^{\mathrm{a}}$ \\
\hline
\end{tabular}

Abbreviations: SCFA, short-chain fatty acids; MCFA, medium-chain fatty acids; LCFA, long-chain fatty acids; SFA, saturated fatty acids; MUFA, monounsaturated fatty acids and PUFA, polyunsaturated fatty acids. Mean values $(n=4)$ with different letters in the same column are significantly different $(P \leq 0.05)$. 
for SCFA contents in conventional fresh milk, yoghurt and fermented milk. In addition, MCFA and LCFA varied slightly in organic and conventional products (Tab. IV).

The highest amounts of saturated fatty acids (SFA) were found in fermented organic milk made with co-cultures St-BL04 and St-BB12 $(P \leq 0.05)$. Contents of polyunsaturated fatty acids (PUFA) averaged $3.61 \mathrm{~g} \cdot 100 \mathrm{~g}^{-1}$ with no significant differences $(P \leq 0.05)$, whereas the lowest content of monounsaturated fatty acids (MUFA) $\left(26.34 \mathrm{~g} \cdot 100 \mathrm{~g}^{-1}\right)$ was found in organic yoghurt with a statistically significant difference $(P \leq 0.05)$ compared to other samples (Tab. IV). The contents of SFA, MUFA and PUFA in organic milk are similar to the data reported by Fanti et al. [13].

No significant difference was found in the concentration of cis-9, trans-11 CLA isomer between the fresh and fermented milk by different co-cultures in the conventional milk. On the other hand, the highest concentration of cis-9, trans-11 CLA was found in organic milk fermented with cocultures St-BB12, St-B94, St-BL04, StLB340 and St-HN019 with a statistically significant difference $(P \leq 0.05)$ versus organic fresh milk. The highest amounts of CLA ( $65 \%$ higher than in the control) were found in organic milk fermented by St-bifidobacteria and yoghurt cultures (Fig. 2). The ability of probiotic bacteria to produce CLA confirms those previously obtained from a survey carried out on dairy products [7, 24, 26].

To explain the observed variations in CLA levels, it should be taken into account that the different enzyme activities of starter cultures have been identified as factors that may contribute to influence the CLA content of cultured dairy products [31]. In particular, Lin et al. [22] demonstrated that a higher level of linoleic acid isomerase produced by Lactobacillus acidophilus in crude extract increased the CLA content of fermented milk.
These results suggest that different strains of bifidobacteria as well as yoghurt cultures grown were able to produce appreciable quantities of CLA in the organic fermented milk.

\subsection{Correlation between linoleic acid (C18:2), TVA (C18:1t), CLA (C18:2 $c$ 9, $t$ 11) and fermentation time $\left(T_{\mathrm{pH} \text {.7. }}\right)$ in organic and conventional milk}

CLA is produced in the rumen mainly through incomplete biohydrogenation of linoleic acid in CLA (C18:2) by ruminal bacteria and by enzymatic action of $\Delta-9$ desaturase upon TVA - C18:1t in mammary glands [15].

In this study, the amount of linoleic acid in fresh organic milk was $1.85 \mathrm{~g} \cdot 100 \mathrm{~g}^{-1}$, and after fermentation a significant decrease $(P \leq 0.05)$ in this FA was found for all employed strains, including yoghurt strains, resulting in an increase in CLA amounts. In fact, a strong negative significant correlation $(r=-0.803, \quad P \leq 0.01) \quad$ was observed between linoleic acid and CLA.

The lower fermentation time observed in organic milk fermented by St-BL04, St-B94 and yoghurt starter cultures (St-LB340) could indicate that there is a relation between short fermentation time and the occurrence of an incomplete biohydrogenation of linoleic acid into CLA by bifidobacteria and yoghurt strains, similarly, what occurs during fermentation process in the rumen. Indeed, a significant negative correlation was found between fermentation time and CLA $(r=-0.450, P \leq 0.01)$, and a significant positive correlation $(r=0.673$, $P \leq 0.01)$ between fermentation time and linoleic acid contents.

These results agree with those reported by Oliveira et al. [26], who observed a higher CLA content in probiotic fermented milk supplemented with different prebiotics, 


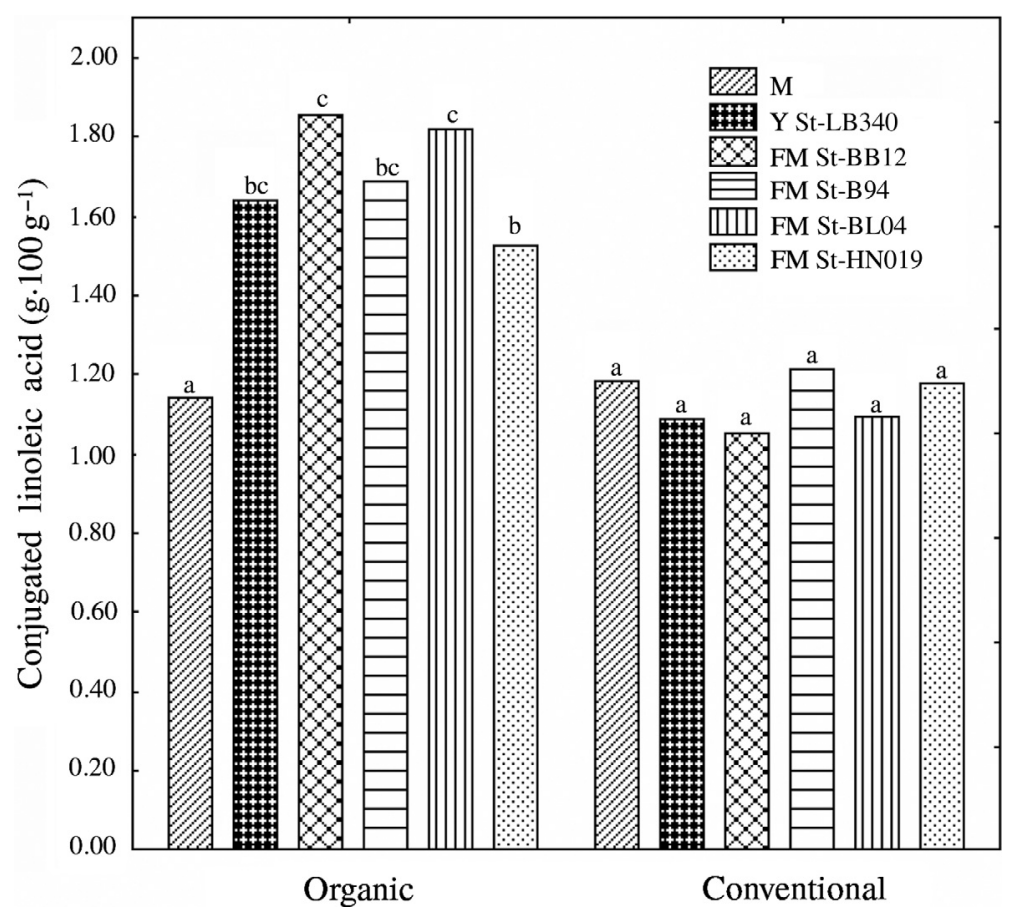

Figure 2. CLA $\left(\mathrm{g} \cdot 100 \mathrm{~g}^{-1}\right)$ in organic and conventional fresh milk (M), yoghurts (St-LB340 control) and by fermented milk $S$. thermophilus in co-culture with the four strains of $B$. animalis subsp. lactis (St-BB12, St-B94, St-BL04 and St-HN019). Mean values $(n=4)$ with different letters are significantly different; $P \leq 0.05$.

which showed a fermentation time lower than control fermented milk (i.e. not supplemented milk). Meanwhile, Florence [14] found that for fermentation carried out with pure cultures of bifidobacteria and L. bulgaricus in which fermentation times were very long $\left(T_{\mathrm{pH} 4.7}>10 \mathrm{~h}\right)$, no significant increase in CLA amounts was found in both milks (conventional and organic) after the process.

Then, probably there is a factor in organic milk which stimulates fast fermentation and allows metabolic biohydrogenation pathway of CLA production.

In parallel, there are higher contents of TVA in fresh and fermented organic milk when compared with conventional products. The higher amounts of TVA are associated with higher contents of CLA with a strong significant positive correlation $(r=0.883$, $P \leq 0.01)$ as previously reported by Molketin and Giesemann [23].

\section{CONCLUSION}

The chemical composition of conventional and organic milk was closely related. All bacteria showed adequate counts according to regulatory recommendations. Despite the fact that no significant differences were noted with the main FA, organic fermented milk showed higher amounts of TVA and CLA. A significant positive correlation was found between fermentation time $\left(T_{\mathrm{pH} 4.7}\right)$ and linoleic acid, as well as between TVA and CLA. Beside, a significant negative 
correlation was observed between linoleic acid and CLA, and between $T_{\mathrm{pH} 4.7}$ and CLA, whatever the type of milk. The differences noted in FA composition and acidification profile are not enough to predict the effect of each bacteria on CLA increase in organic fermented milk. Thus, new studies are required to elucidate the observed data.

Acknowledgments: The authors thank Danisco Brasil Ltda (Cotia, São Paulo, Brazil), Chr. Hansen and DSM Food Specialities for the donation of cultures, FAPESP and $\mathrm{CNPq}$ for financial support, and Professor C. Colli from São Paulo University, Department of Food Science for the analysis of major and trace mineral elements.

\section{REFERENCES}

[1] Ackman R.G., Application of gas liquid chromatography to lipid separation and analysis: qualitative and quantitative analysis, in: Chow C.K. (Ed.), Fatty Acids in Foods and Their Health Implications, CRC Press, Boca Raton, USA, 2007, pp. 47-62.

[2] Almeida K.E., Tamime A.Y., Oliveira M.N., Influence of total solids contents of milk whey on the acidifying profile and viability of various lactic acid bacteria, LWT - Food Sci. Technol. 42 (2009) 672-678.

[3] AOAC, Official Methods 965.09, 968.08, 985.35, 17th Edn., Gaithersburg, MD, USA, 2000.

[4] AOCS, Official Method Ce 1-62: fatty acid composition by gas chromatography, Official Methods and Recommended Practices of the AOCS, American Oil Chemists Society, Champaign, IL, USA, 1997.

[5] Bergamo P., Fedeli E., Iannibelli L., Marzillo G., Fat-soluble vitamin contents and fatty acid composition in organic and conventional Italian dairy products, Food Chem. 82 (2003) 625-631.

[6] Bisig W., Eberhard P., Collomb M., Rehberger B., Influence of processing on the fatty acid composition and the content of conjugated linoleic acid in organic and conventional dairy products - a review, Lait 87 (2007) 1-19.
[7] Coakley M., Johnson M.C., McGrath E., Rahman S., Ross P., Fitzgerald G.F., Devery R., Stanton C., Intestinal bifidobacteria that produce trans-9, trans11 conjugated linoleic acid: a fatty acid with antiproliferative activity against human colon SW480 and HT cancer cells, Nutr. Cancer 56 (2006) 95-102.

[8] Collomb M., Schmid A., Sieber R., Wechsler D., Ryhänen E.L., Conjugated linoleic acids in milk fat: variation and physiological effects, Int. Dairy J. 16 (2006) 1347-1361.

[9] Croissant A.E., Washburn S.P., Dean L.L., Drake M.A., Chemical properties and consumer perception of fluid milk from conventional and pasture-based production systems, J. Dairy Sci. 90 (2007) 4942-4953.

[10] Dave R.I., Shah N.P., Evaluation of media for selective enumeration of Streptococcus thermophillus, Lactobacillus delbrueckii subsp. bulgaricus, Lactobacillus acidophilus and bifidobacteria, J. Dairy Sci. 79 (1996) 1529-1536.

[11] Ekinci F.Y., Okur O.D., Ertekin B., GuzelSeydim Z., Effects of probiotic bacteria and oils on fatty acid profiles of cultured cream, Eur. J. Lipid Sci. Technol. 110 (2008) 216-224.

[12] Fall N., Emanuelson U., Martinsson K., Jonsson S., Udder health at a Swedish research farm with both organic and conventional dairy cow management, Prev. Vet. Med. 83 (2008) 186-195.

[13] Fanti M.G.N., Almeida K.E., Rodrigues A.M., Silva R.C., Florence A.C.R., Gioielli L.A., Oliveira M.N., Contribuição ao estudo das características físico-químicas e da fração lipídica do leite orgânico, Ciênc. Tecnol. Aliment. 28 (2008) 249-255.

[14] Florence A.C.R., Perfil tecnológico de cepas de bifidobactéria em cultura pura e em co-cultura com Streptococcus thermophilus em leites orgânico e convencional, Master Thesis, Universidade de São Paulo, Brazil, 2009.

[15] Gnädig S., Xue Y., Berdeaux O., Chardigny J.M., Sebedio J.-L., Conjugated linoleic acid (CLA) as a functional ingredient, in: MattilaSandholm T., Saarela M. (Eds.), Functional Dairy Products, CRC Press, USA, 2003, pp. 263-298.

[16] Gobbetti M., Minervini F., Rizzello C.G., Angiontensin I-convertin-enzyme-inhibitory 
and antimicrobial bioactive peptides, Int. J. Dairy Tech. 57 (2004) 173-187.

[17] Instituto Adolfo Lutz, Normas analíticas do Instituto Adolfo Lutz: métodos químicos e físicos para análise de alimentos, 3rd Edn., Vol. 1. Imprensa Oficial do Estado de São Paulo, São Paulo, Brazil, 1985, 533 p.

[18] ISO, Standard 14156, Milk and Milk Products - Extraction Methods for Lipids and Liposoluble Compounds, ISO, Geneva, Switzerland, 2001.

[19] ISO, Standard 15884, Milk Fat - Preparation of Fatty Acid Methyl Esters, ISO, Geneva, Switzerland, 2002.

[20] Izco J.M., Tormo M., Jiménez-Flores R., Rapid simultaneous determination of organic acids, free amino acids, and lactose in cheese by capillary electrophoresis, J. Dairy Sci. 85 (2002) 2122-2129.

[21] Kepler C.R., Tucker W.P., Tove S.B., Biohydrogenation of unsaturated fatty acids IV. Substrate specificity and inhibition of linoleic delta-12-cis, delta-11-trans-isomerase from Butyrivibrio fibrisolvens, J. Biol. Chem. 245 (1970) 3612-3620.

[22] Lin T.Y., Lin C.W., Wang Y.J., Production of conjugated linoleic acid by enzyme extract of Lactobacillus acidophilus, Food Chem. 83 (2003) 27-31.

[23] Molketin J., Giesemann A., Differentiation of organically and conventionally produced milk by stable isotope and fatty acid analysis, Anal. Bioanal. Chem. 388 (2007) 297-305.

[24] Oh D.K., Hong G.H., Lee Y., Min S.G., Sin H.S., Cho S.K., Production of conjugated linoleic acid by isolated Bifidobacterium strains, World J. Microbiol. Biotechnol. 19 (2003) 907-912.

[25] Oliveira M.N., Damin M.R., Efeito do teor de sólidos e da concentração de sacarose na acidificação, firmeza e viabilidade de bactérias do iogurte e probióticas em leite fermentado, Ciênc. Tecnol. Aliment. 23 (2003) 172-176.

[26] Oliveira R.P.S., Florence A.C.R., Silva R.C., Perego P., Converti A., Gioielli L.A., Oliveira M.N., Effect of different prebiotics on the production of nonfat symbiotic fermented milk, Int. J. Food Microbiol. 128 (2009) 467-472.

[27] Pariza M.W., Hargraves W.A., A beefderived mutagenesis modulator inhibits initiation of mouse epidermal tumor by 7,12-dimethylbenz[ $a]$ anthracene, Carcinogenesis 6 (1985) 591-593.
[28] Rainio A., Vahvaselka M., Suomalainen T., Laakso S., Production of conjugated linoleic acid by Propionibacterium freudenreichii ssp. shermanii, Lait 82 (2002) 91-101.

[29] Saccaro D.M., Tamime A.Y., Oliveira M.N., The viability of three probiotic organisms grown with yoghurt starter cultures during storage for 21 days at $4{ }^{\circ} \mathrm{C}$, Int. J. Dairy Technol. 62 (2009) 397-404.

[30] Salas-Salvadò J., Marquez-Sandoval F., Bullo M., Conjugated linoleic acid intake in humans: a systematic review focusing on its effect on body composition, glucose, and lipid metabolism, Crit. Rev. Food Sci. Nutr. 46 (2006) 479-488.

[31] Sieber R., Collomb M., Aeschlimann A., Jelen P., Eyer H., Impact of microbial cultures on conjugated linoleic acid in dairy products $-\mathrm{a}$ review, Int. Dairy J. 14 (2004) 1-15.

[32] Toledo P., Andrén A., Bjorck L., Composition of raw milk from sustainable production systems, Int. Dairy J. 12 (2002) 75-80.

[33] Valle P.S., Lien G., Flaten O., Koesling M., Ebbesvik M., Herd health and health management in organic versus conventional dairy herds in Norway, Livest. Sci. 112 (2007) 123-132.

[34] Vasiljevic T., Shah N.P., Probiotics - from Metchnikoff to bioactives, Int. Dairy J. 18 (2008) 714-728.

[35] Venturoso R.C., Almeida K.E., Rodrigues A.M., Damin M.R., Oliveira M.N., Determinação da composição físico-química de produtos lácteos: estudo exploratório de comparação dos resultados obtidos por metodologia oficial e por ultra-som, Rev. Bras. Ciênc. Farm. 34 (2007) 607-613.

[36] Vicini J., Etherton T., Kris-Etherton P., Joan Ballam R.D., Steven Denham M.S., Staub R., Goldstein D., Roger Cady M.D., McGrath M., Lucy M., Survey of retail milk composition as affected by label claims regarding farm management practices, J. Am. Diet. Assoc. 108 (2008) 1198-1203.

[37] Xu S., Boylston T.D., Glatz B.A., Conjugated linoleic acid content and organoleptic attributes of fermented milk products produced with probiotic bacteria, J. Agric. Food Chem. 53 (2005) 9064-9072.

[38] Żegarska Z., Paszczyk B., Borejszo Z., Conjugated linoleic acid (CLA) and trans $\mathrm{C} 18: 1$ and $\mathrm{C} 18: 2$ isomers in fat of some commercial dairy products, Pol. J. Nat. Sci. 23 (2008) 248-256. 